\title{
ЭКОНОМИЧЕСКОЕ ОБРАЗОВАНИЕ ВОСТОЧНОЙ СИБИРИ В ХХ СТОЛЕТИИ: ОТВЕТЫ НА МОДЕРНИЗАЦИОННЫЕ ВЫЗОВЫ
}

Рецензия на монографию: Суходолов А. П. «Храм науки» или «фабрика кадров»: к историческим предпосылкам дискуссии об опорном университете Байкальского региона / А.П. Суходолов, Д. Я. Майдачевский. - Иркутск : Издво БГУ, 2017. - 92 с.

\section{ECONOMIC EDUCATION OF EASTERN SIBERIA IN THE 20 ${ }^{\text {TH }}$ CENTURY: ANSWERING INNOVATION'S CHALLENGES}

Review of the monograph "The Temple of Science» or "the personnel factory»: to the historical preconditions of the discussion about a flagship university of the Baikal region" by Alexander P. Sukhodolov and Dmitry Ya. Maidachevsky. Irkutsk, BGU Publ., 2017. 92 p.

Современные глобализационные процессы требуют новых подходов к формированию и функционированию рынка образовательных услуг. В условиях реформирования всей системы экономических отношений особое место занимает подготовка квалифицированных кадров для сферы предпринимательства. Главной целью экономического образования является достижение соответствия результатов деятельности государственных учебных заведений потребностям современного этапа развития рыночной экономики для малого, среднего и крупного бизнеса. Очевидно, что в настоящее время образование, в том числе бизнес-образование, очень многогранно и становится определяющим фактором становления предпринимательской среды, развития производительных сил, как в целом в Российской Федерации, так и в стратегически значимых регионах, к которым относится Сибирь и Дальний Восток.

Рыночная экономика предъявляет повышенные требования к руководителям предприятий и организаций всех уровней. Система подготовки и переподготовки квалифицированных кадров должна не только отвечать этим требованиям, но и работать на опережение. В связи с этим, роль и значение качества обучения, его соответствие образовательным стандартам постоянно возрастают, что подчеркивает актуальность проблем, поднятых авторами в данном исследовании.

Во главу угла работы поставлен исторический аспект формирования и развития экономического образования в Сибири, что чрезвычайно важно для понимания его современного состояния. В работе представлен глубокий анализ возникновения и развития коммерческого образования в России в разных временных интервалах. На примере сибирского региона авторы последовательно исследуют историческую ретроспективу становления и развития высшей школы, связывая ее с отечественными волнами модернизации страны. Свои выводы авторы подтверждают ссылками на многочисленные публикации, в том числе раритетные.

(C) E. A. Трофилов, 2017

\section{Baikal Research Journal}

электронный научный журнал Байкальского государственного университета 
Опираясь на содержательный обширный архивный материал, они показывают, с исторической и общественно-политической точек зрения, определяющую роль министра финансов тех лет и просто выдающейся личности С. Ю. Витте в создании и реформировании коммерческого образования в Российской империи.

Определяющими задачами монографии, сформулированными авторами, являются: изучение этапов начала подготовки кадров для коммерческих сегментов деятельности, как реакции на развитие производительных сил в дореволюционную эпоху; характеристика учебных заведений по подготовке экономических кадров; рассмотрение специфики обучения в различных социально-экономических формациях; изучение роли и значения подготовки экономических кадров в условиях административно-командной системы планирования единого народнохозяйственного комплекса страны.

Структура исследования построена логично и обосновано. Работа состоит из введения, трех глав и заключения. Содержание работы базируется на изучении и осмыслении обширной статистической, научной, фактической и библиографической отечественной и зарубежной литературы.

Выполненный аналитический обзор большого количества научных источников, позволил авторам последовательно рассмотреть основные этапы становления и развития предпринимательства и подготовки коммерческих кадров для дореволюционной России в целом и сибирских регионов в частности. На рубеже $\mathrm{XIX-XX} \mathrm{вв.} \mathrm{начинается} \mathrm{бурное} \mathrm{развитие} \mathrm{капитализма} \mathrm{в} \mathrm{России:} \mathrm{привлекаются}$ зарубежные капиталы, особенно европейские; начинается строительство новых и модернизация существующих заводов и предприятий; идет освоение Сибири и Дальнего Востока; открываются месторождения полезных ископаемых; успешно развивается сельское хозяйство в данных регионах; осуществляется один из самых грандиозных проектов того времени - строительство Транссибирской магистрали, соединяющей отдаленные территории страны с центром Российской империи, что в свою очередь способствовало усилению связей со странами Азиатско-Тихоокеанского региона.

Вышеперечисленные факторы со всей остротой поставили перед обществом задачу формирования интеллектуальной элиты сибирских регионов, квалифицированных кадров, адекватно соответствующих данному этапу развития российского общества и экономики. Для этого и создавались новые учебные заведения в Сибири, в частности в Иркутской губернии. Реформа образования С.Ю. Витте имела своей целью подготовку кадров для экономики, в связи с чем первоначально была выстроена стройная система коммерческого образования. Она включала в себя три типа учебных заведений - коммерческие курсы, торговые школы и классы, а также средние коммерческие училища. Причем училища были открыты для всех сословий. Таким образом, наблюдалось подчинение образовательной политики потребностям модернизации (индустриализации) страны.

Во второй главе рассматривается период революционных потрясений 19171918 гг., когда в 1918 г. в Иркутске наконец-то образуется университет. Постреволюционный период характеризуется сосуществованием двух подходов в организации образования: прагматичного, для удовлетворения потребностей бурно развивающейся в предвоенные годы экономики СССР, и чисто научного, рассчитанного на формирование интеллектуального слоя населения (для обслуживания судейского и адвокатского корпусов, врачей, научных сотрудников, преподавателей школ и т.д.). Эти два начала присутствовали, развивались и конкурировали друг с другом в системе высшего образования Восточной Сибири по многим направлениям, в том числе в финансовой сфере, так как приходилось бороться за «скудные бюджетные средства» в ходе в индустриализации (с. 42). В борьбе сторонников и противников

\section{Baikal Research Journal}

электронный научный журнал Байкальского государственного университета 
двух начал развития высшей школы региона отражался и процесс смены интеллектуальных элит общества. «Белая кость» интеллигенции хотела быть ближе к власти, получать от нее деньги, заниматься чистой наукой. «Черная кость» была связана с производством, видела свое призвание в подготовке кадров для реальной экономики. Этот процесс смены элит абсолютно точно схвачен в названии книги.

В третьей главе показано развитие высшего образования в Иркутске в послевоенную хрущевскую эпоху: 1950-е и первая половина 1960-х гг. В этот период, отмечают авторы, базируясь на потенциальных возможностях страны, осуществляется отказ от догоняющего пути модернизации экономики в пользу опережающего развития. Однако данное направление сталкивается с непоследовательностью и противоречивостью партийной образовательной политики.

Проблема, поднятая авторами в монографии относительно того, какой вуз следует исторически признать опорным для региона, безусловно, является дискуссионной. Но, как известно, в спорах рождается истина. Монография А. П. Суходолова и Д. Я. Майдачевского имеет подзаголовок: «К 110-летию экономического образования в Восточной Сибири». Поэтому желательно продолжить освещение данной проблемы в более поздние периоды развития Иркутской области, том числе в условиях рыночной экономики. В связи с этим представляет интерес анализ региональной системы бизнес-образования, а также подготовки высококвалифицированных кадров для Иркутской области в свете новых вызовов современности: формирование шестого экономического уклада в развитых странах, отток талантливой молодежи из районов Сибири, отсутствие научно-обоснованной стратегии использования человеческого капитала в Иркутской области и др.

Данная монография адресована научным работникам, государственным и муниципальным служащим, руководителям образовательных учреждений, краеведам и широкому кругу читателей, интересующихся проблемами развития высшего образования в Сибири.

\section{Информация об авторе}

Трофимов Евгений Александрович — доктор экономических наук, профессор, кафедра экономической теории и институциональной экономики, Байкальский государственный университет, 664003, г.Иркутск, ул. Ленина, 11, e-mail: TrofimovEA@bgu.ru.

\section{Author}

Evgeniy A. Trofimov - Doctor of Economics, Professor, Chair of Economic Theory and Institutional Economy, Baikal State University, 664003, Irkutsk, 11 Lenin St., e-mail: TrofimovEA@bgu.ru.

\section{Для цитирования}

Трофимов Е. А. Экономическое образование Восточной Сибири в XX столетии: ответы на модернизационные вызовы / Е. А. Трофимов // Baikal Research Journal. — 2017. T. 8, № 4. - DOI : 10.17150/2411-6262.2017.8(4).30. - Рец. на мон.: Суходолов А. П. «Храм науки» или «фабрика кадров»: к историческим предпосылкам дискуссии об опорном университете Байкальского региона / А.П. Суходолов, Д. Я. Майдачевский. - Иркутск : Изд-во БГУ, 2017. - 92 с.

\section{For Citation}

Trofimov E. A. Economic education of Eastern Siberia in the 20th century: answering innovation's challenges (Review of the monograph «The Temple of Science» or «the personnel factory»: to the historical preconditions of the discussion about a flagship university of the Baikal region» by Alexander P. Sukhodolov and Dmitry Ya. Maidachevsky). Irkutsk, BGU Publ., 2017. 92 p. Baikal Research Journal, 2017, vol. 8, no. 4. DOI: 10.17150/24116262.2017.8(4).30. (In Russian).

\section{Baikal Research Journal}

